\title{
How is Mothers' Characteristics of Toddlers Below the Red Line?
}

\author{
Nurshe Aliviolla Azmi ${ }^{1}$, Malik Afif ${ }^{2)}$ \\ Department of Health Promotion and Behavior Science, Faculty of Public Health, Universitas \\ Airlangga, Surabaya, Indonesia \\ 2 East Java Provincial Health Office, Surabaya, Indonesia \\ Email: nurshe.aliviolla.azmi-2017@fkm.unair.ac.id
}

\begin{abstract}
Background: Below the Red Line is the main cause of death among children $<5$ years old. Indonesia is one of the countries that still have some nutritional problems such as malnutrition, short nutrition and over nutrition, leading to $54 \%$ of deaths among children under five years old. Toddlers aged 12-59 months in Surabaya are still suffering from malnutrition despite receiving health services from the puskesmas. That is caused by several factors influencing the mother's role in taking care of her children. Objective: This study aimed to describe the mother's characteristic of the Red Line incidence among children. Methods: The population in this study were 691 toddlers aged 12-24 months with 31 toddlers in Below the Red Line category in Puskesmas Wonokusumo, Surabaya. The sample was taken using a simple random sampling method. Data analysis was conducted using descriptive analysis with percentage and frequency distribution techniques. Results: The data showed that 69.8\% of the mothers aged 21-30 years are classified in the healthy reproductive period. As many as $81.1 \%$ of them are unemployed, 49.1\% graduated from elementary school, and $52.8 \%$ have adequate knowledge. Conclusion: Mothers' participation to Integrated Healthcare Center or Pos Pelayanan Terpadu (Posyandu) to rose their knowledge about nutritional status. Mothers will get information delivered by cadres and health workers through the counseling desk at Posyandu.
\end{abstract}

Keyword: Below the Red Line, Factors, Malnutrition, Nutrition Interventions

\section{INTRODUCTION}

Below the Red Line (BRL) is a condition of children under-five years old who experience growth disorders due to malnutrition which indicated by underweighed on $<5$ years old children, which is the sign of Below the Red Line on Kartu Menuju Sehat (KMS), poor nutritional status (BW/A<-3 SD), and the presence of clinical signs.

Kartu Menuju Sehat (KMS) is a card that contains a growth curve for children $<5$ years old based on the anthropometric index of Body Weight by Age $(\mathrm{BW} / \mathrm{A})$ which functions as a tool to monitor the health and growth of children $<5$ years old. Kartu Menuju Sehat (KMS) can indicate the nutritional status of children $<5$ years old. Toddlers in the green area/color shows adequate nutrition, while the yellow color shows malnutrition status, and below the Red Line indicates the poor nutritional status (Indonesian Ministry of Health, 2010).
Nutritional status of children $<5$ years old can determine the quality of public health since they are considered as the next generation who should be nurtured in order to continue the nation's development. Nutrition problems for children $<5$ years old in Indonesia at this time are having growth problem with weight Below the Red Line. As many as $54 \%$ of children $<5$ years old deaths were caused by Below the Red Line which also the main cause of infant mortality in the world. Among children under the Red Line are classified into a state of severe malnutrition caused by low consumption of energy and protein from daily food and occurs in a long time (Novitasari, Destriatania and Febry, 2016).

The poor nutritional status in toddlers will affect their future where malnutrition is the leading problem. It will not only have short-term effects such as the infants' vulnerability to infectious diseases, low survival ability, low IQ, low cognitive abilities and also deaths for the 
long-term effect (Rahma and Nadhiroh, 2016).

The number of health targets for children $<5$ years old in 2018 in Indonesia was very large at around $19,270,715$ or $7.5 \%$ of the total population (Indonesian Ministry of Health, 2018). Therefore, the quality of growth and development of toddlers in Indonesia needs serious attention. Getting good nutrition, adequate stimulation and affordable quality health services including early detection and intervention of growth and development disorders. The toddler period is a critical period and cannot be repeated, the golden period for the survival of the child's growth and development, if there is a disorder in growth and development that is not detected, it may become untreated and difficult to cure (Larasati, 2019).

Indonesia is one of the countries that still has several nutritional problems such as poor nutrition, malnutrition, short nutrition, and over nutrition. Based on Riset Kesehatan Dasar (2018) the prevalence of malnutrition problems among children aged 0-59 months according to the BW/A index in 2013 was $19.6 \%$, decreased to be $17.7 \%$ in 2018 . It showed that the prevalence were high, exceeding the target of National Medium Term Development Plan/Rencana Pembangunan Jangka Menengah Nasional (RPJMN) which was $17 \%$ (RISKESDAS, 2018).

The results of Riset Kesehatan Dasar East Java data observing in 2013 showed that the prevalence of malnutrition children aged 0-59 months were $4.9 \%$, and the prevalence of malnutrition children in 2018 were $3.35 \%$ (Indonesian Ministry of Health, 2018). In East Java, there are still many toddlers experiencing malnutrition.

On the other hand, according to Surabaya City Health Office information in 2015 , the percentage of children $<5$ years old Below the Red Line were $0.7 \%$, increased to $0.76 \%$ in 2016 (Surabaya City Health Office, 2016a). However, in 2017, the prevalence of toddlers Below the Red Line decreased in small number by $0.64 \%$ (Surabaya City Health Office, 2017). Based on data from the Surabaya City Health Office, the status of Below Red Line of children $<5$ years old in Pos Pelayanan Terpadu or Integrated Healthcare Center (Posyandu) throughout
Surabaya in 2017 was $0.66 \%$ with a total of 1,193 children out of 179,662 . Even though in Surabaya the case of malnutrition has decreased, malnutrition problem is not completely gone and it needs to be considered to prevent malnutrition in Surabaya from increasing because in Surabaya there are still mothers who lack knowledge about nutrition which affect the intake given to their children.

The number of children Below the Red Line (BRL) in Puskesmas Wonokusumo in 2017 were $2.07 \%$. The high number of children $<5$ years old Below the Red Line in Surabaya, especially in Puskesmas Wonokusmo is exceeding the target of malnutrition prevalence $<1 \%$ (Surabaya City Health Office, 2016b). This happened due to several factors. There are still toddlers with malnutrition in Surabaya which can influence development in Indonesia as the result of incapability to improve the quality of human resources' life.

Surabaya City Health Office has made several malnutrition treatment programs to reduce malnutrition problems in Surabaya such as supplementary feeding or Pemberian Makanan Tambahan (PMT), counseling, and home visits (Surabaya City Health Office, 2017). Almost all of Puskesmas in Surabaya provide health services for children $<5$ years old Below the Red Line. There are still high case from malnutrition although they are receiving health services. Especially in the area of Puskesmas Wonokusumo where there were 80 infants $(1.93 \%)$ Below the Red Line whom still exceed the target of the Strategic Plan by $<1 \%$. This study aimed to determine the description of Below the Red Line incidence in children $<5$ years old in Puskesmas Wonokusumo, Semampir (district), Surabaya.

\section{METHOD}

This research was a descriptive study. The population in this study were 691 toddlers aged 12-24 months and 31 Below the Red Line toddlers. This study used Simple Random Sampling with total sample were 53 toddlers aged 12-24 months. 38 toddlers were in good nutrition, 5 toddlers were in short nutrition (yellow line), and 10 toddlers are poor nutrition (red line). 
The research setting was on Puskesmas Wonokusumo Surabaya and the scheduled research was on August 2019 to October 2019. The data collection technique used primary data obtained by direct interviews to the toddlers' mothers. Interview was conducted by visiting the mothers' residence and using questionnaire media. Secondary data was obtained from the Puskesmas Wonokusumo data and KMS toddlers in the Posyandu Wonokusumo, Semampir. Data analysis used descriptive analysis with percentage and frequency distribution techniques. Variabels was age, occupation, education and knowledge about nutritional status of toolders.

\section{RESULT AND DISCUSSION}

\section{Description of Mothers' Age Towards Below the Red Line Incidence}

According to the results of previous research, the characteristics of mothers of toddlers aged 12-24 months consist of age, education, occupation and family income were grouped into normal and abnormal nutritional status. Based on age, $48.9 \%$ mothers of toddlers $<5$ years old were 26-35 years old. If they were grouped according to the nutritional status of toddlers aged 12-24 months, mothers who are $<35$ years old had more toddlers with normal nutritional status $(80.8 \%)$ -

Mother's age is one of the factors that can indirectly affect nutritional status in infants among the other factors. This study showed that the mothers were relatively young $(<35$ years) that they did not have sufficient knowledge yet about nutrition during pregnancy and postpartum (Puspasari and Andriani, 2017).

According to the other research results, based on respondents' age characteristics, it was found that as many as 32 mothers were in vulnerable age group (15-20 years old). Knowledge is influenced by age, experience, and education. The more matured a person's age is, the more that person will have matured way of thinking (Rahmatillah, 2018). Mother's age is one of the indirect factors, and being classified as young, means the mother still lacks knowledge about good nutrition for their children, so that children become vulnerable to malnutrition.

Table 1. Distribution of Respondents' characteristics in Puskesmas Wonokusumo, Surabaya

\begin{tabular}{lrr}
\hline \multicolumn{1}{c}{ Characteristics } & $\mathbf{n}$ & \multicolumn{1}{c}{$\%$} \\
\hline Age (Years) & & \\
\hline $21-30$ & 37 & 69.8 \\
$31-40$ & 15 & 28.3 \\
$>40$ & 1 & 1.9 \\
\hline Occupation & & \\
\hline Employed & 10 & 18.9 \\
Unemployed & 43 & 81.1 \\
\hline Education & & \\
\hline No education & 1 & 1.9 \\
Elementary School & 26 & 49.1 \\
Junior High School & 12 & 22.6 \\
Senior High School & 12 & 22.6 \\
College & 3 & 3.8 \\
\hline Knowledge & & \\
\hline Good (76-100\%) & 22 & 41.5 \\
Adequate $(56-75 \%)$ & 28 & 52.8 \\
Insufficient $(<56 \%)$ & 3 & 5.7 \\
\hline Total & 53 & 100 \\
\hline
\end{tabular}

Description of Mothers' Occupation towards Below the Red Line Incidence Based on the research, $18.9 \%$ of employed mothers, $13.2 \%$ of them were having toddlers Below the Red Line while $5.6 \%$ were in good nutrition status. The mothers' employment status affected the lack of parenting and supervision towards their children. According to the interview results, one of the respondents was actively working mother and she admitted that she did not visit Posyandu routinely so that she had minimum information about Below the Red Line.

In Wonokusumo, there were as many as $13.2 \%$ of toddlers Below the Red Line with employed mothers. This situation happened because the mothers need steady income to fulfil family needs, including food to provide proper nutritions for the whole family. However, this situation had reduced the mothers' time to take care of their children such as preparing for food and nurturing the children.

According to the results of previous research regarding the mothers' occupational status, it was classified into unemployed, employed, entrepreneurs, farmers/fishermen/laborers, and others in this study. Based on the mothers' occupation, $82.9 \%$ of the mothers were unemployed. 55.3\% toddlers aged 12-24 months showed normal status with unemployed mothers' classification. It showed that there is no significant 
relationship between mother's occupational status and the toddlers' nutritional status. The mothers' occupational status was not related to the children's nutritional status (BW/A) since if most of them did not work then they could not fulfil their family needs. Mothers' occupation could be influenced by their level of education. The higher the level of education was, the higher chance of getting better job (Puspasari and Andriani, 2017).

This study is in line with the results of research done in 2016, which revealed that 62 respondents showed no significant relationship between mothers' occupation with the children's nutritional status. Mothers who were working tend to lose time to give better food intake for their toddlers and affected the toddlers' nutritional status. Mothers who worked had more underweight nutritional status than mothers did not (Rozali, Subagyo and Widhiyastuti, 2016).

The biggest negative impact for working mothers or having outside routine activites was neglecting their children. The children's development is influenced by parenting and nutritional conditions until 5 years old since the stages are important for their growth. At that age, children cannot provide their own needs and only depend on their mothers or caregivers (Nurul Budi Lestari1, 2016).

The results of this study was in line with the results study in India which showed that even though malnourished children had more employed mothers than unemployed ones $(15 \% \mathrm{v} / \mathrm{s} 12.17 \%)$ but in the proportion of children's nutrition to mothers occupation status was found to be insignificant (Notoatmodjo, 2010). So that the mother works to influence the nutritional status of her child, because toddlers under 5 years old are golden periods that affect their growth and that period is a critical period and cannot be repeated, and the mother's role is very important for parenting that influences her child's growth and development.

\section{Description of Mothers' Education towards Below the Red Line Incidence \\ Based on the data, $49.1 \%$ of the mothers of children Below the Red Line had elementary school education and $61.5 \%$ mothers who graduated from elementary school had good nutritional status. It can be concluded that education}

level influences the way a person obtains information. Someone with a proper level of education will provide good care for their children.

Based on Puspasari's research in 2017, mothers' education means the last education finished by them. $42.5 \%$ of mothers with 12-24 months old toddlers had elementary/Islamic-based elementary schools as their last education. Among mothers who graduated from elementary school, as many as $25.5 \%$ had toddlers with normal nutritional status while $17.0 \%$ had abnormal nutritional status. The level of education plays an important role in public health. Parents with higher and more proper education tend to choose foods with balanced nutrition and make sure the children's nutritional needs are fulfilled (Puspasari and Andriani, 2017).

The result of study administered in 2016 revealed that mothers did not go to the Posyandu routinely might influenced by the low level of education related to their children's nutritions. As many as $67.9 \%$ of mothers had low education level. Lack of education would make it difficult for mothers to receive and understand the information especially in the importance of monitoring their toddlers growth through Posyandu visits. The low education level also affected the mothers' participation in Posyandu. Moreover, Posyandu is also the source of information and a place to increase knowledge for mothers of toddlers $<5$ years old (Novitasari, Destriatania and Febry, 2016).

The study is also in line with the results of other research in Surakarta. In this study, there is a relationship between mothers' education level and the nutritional status of children $<5$ years old. It is because the level of mothers' education will affect the attitudes and mindset of mothers in giving attention to food intake of toddlers starting from searching, obtaining, and receiving various information about nutrition toddlers' food intake so that it will affect food selection that determine the toddlers' nutritional status (Rozali, Subagyo and Widhiyastuti, 2016).

Other research in Nigeria suggested that mothers' education play a major role in determining the nutritional status of children. Most of the study results showed that the mothers' low education level was the main determining 
factor of malnutrition (Boma et al., 2014). Therefore, the high education level affected the children's nutritional status related to receiving information, sorting needs of food in order to balance children's nutrition. However, the level of education was not sophisticated unless the mothers visit Posyandu routinely to obtain the latest information related to their children's nutritional status.

\section{Description of Mothers' Knowledge towards Below the Red Line Incidence}

Based on the data, $35.7 \%$ of the mothers of children with Below the Red Line had less knowledge compared to $64.2 \%$ of those with less knowledge having children with good nutritional status. According to those results, it is known that mothers' knowledge about children's growth is one of the factors that can influence toddlers' nutritional status. Mothers who have sufficient knowledge were supposed to be able to monitor their children's growth. Mothers' nutritional knowledge can be influenced by age, education, knowledge, occupation and income.

It was easier to monitor children's growth for the mothers who had adequate knowledge about children's growth and if disorder is found, it can be prevented or treated immediately. This is in line with the results of the study that $86.7 \%$ mothers with adequate knowledge tend to have no children $<5$ years old Below the Red Line. Adequate or bad mother's knowledge is also influenced by the mothers' participation in Posyandu because mothers who go to the Posyandu routinely will get information delivered by cadres and health workers through the counseling desk at the Posyandu (Novitasari, Destriatania and Febry, 2016).

This study was also in line with other research in 2017. It was revealed that as many as $57.5 \%$ of mothers with knowledge about nutrition had toddlers with normal nutritional status while $2.1 \%$ of them had toddlers with abnormal nutritional status. Mothers' knowledge was correlated to the children's nutritional status (BW/A). Mothers' high level of knowledge on nutrition could affect toddlers' diet and nutritional status (Puspasari and Andriani, 2017).

This study was different from a research in Nokilalaki Public Health
Center, which showed that the respondents' level of knowledge had no effect towards Below the Red Line incidence. It was because the mothers routinely brought their children to the Posyandu to get vaccines, therefore, the toddlers' immune level improved and not susceptible to disease as well as weighing regularly to see the development of a toddlers' weight in order to avoid the Below the Red Line incidence and often participated in health education, and had received nutritious food in the form of supplementary feeding (Purnama Sari, Laenggeng and Tasya, 2016).

Sophisticated mothers' knowledge about nutrition will make it easier to take care of their children, especially giving attention to children's food intake so that the nutritional status is good. While mothers with inadequate knowledge about nutrition can result in reduced ability to apply information in daily life which is one of the causes of nutritional disorders (Notoatmodjo, 2010). Therefore, it is important for mothers to get information in order to increase knowledge related to good nutritional status for their children, and can prevent their children from being in the red line or below the red line and become prone to experience malnutrition.

\section{Intervention of Children Below the Red Line}

Indonesia experiences nutrition problems in children $<5$ five years old. In order to overcome this problem, the National Movement for the Acceleration of Nutrition Improvement was carried out in the first thousand days of life (1000 HPK) (Rosha et al., 2016).

The cause of Below the Red Line is because many toddlers experience malnutrition and then become malnourished from the late treatment. The role of the mother is the main role for nutrition problems in children. The factors include relatively young age, mother's education, occupation and mothers' knowledge of nutritional status in parenting for their children. In Indonesia, both in preventing and overcoming malnutrition incidence is growth monitoring. This growth monitoring activity is aimed at preventing nutritional problems with regular weighing activities for children five years old at the Posyandu, but overcoming 
nutrition problems depends on active participation from the public and support from health workers for the importance of participating regularly at the Posyandu.

Mothers who are not actively visiting Posyandu have less of information about the importance of the nutritional status of children under-five years old. They also do not get support from health workers if their toddlers have health problems, as well as monitoring the growth which cannot be monitored optimally. (Fitriani, 2018).

The next intervention is the Supplementary Feeding Activity (SFA). This program is a food supplementation program to improve the nutritional status of malnourished children. SFA is given for children aged 6-11 months in the form of Complementary Food for Breastmilk IMakanan Pendamping Air Susu Ibu (MPASI) or blended food for children aged 1 (Purnama Sari, Laenggeng and Tasya, 2016).

Biscuits are given as much as 75 grams/day and milk powder as much as 80 grams/day to the 2-59 months old toddlers. Giving SFA must be considered based on the critical growth period of children (Inayah and Hartono, 2016).

The Nutrition Awareness Family Program/Program Keluarga Sadar Gizi (KADARZI) is also a program dealing with nutritional problems supported by the toddlers' family in practicing good nutritional behavior, such as weighing regularly, giving only breast milk to babies from birth to 6 months, eat a variety of foods, using iodized salt and nutritional supplement drinks as recommended (Rachmayanti, 2017).

According to research result in Wonokusumo village, Surabaya regarding the implementation of the KADARZI program, it has not been optimized since most of the families did not know and understand the program. Therefore, the role of health workers is needed to maximize home visits program to toddlers below the red line or have poor nutritional status to explain information related to KADARZI (Rachmayanti, 2017).

Various malnutrition prevention programs carried out by the government, often experience failure or the program will stop with the cessation of existing funds (Lisang, 2017). This happened because the planning and decision-making process in development programs is often carried out from the top down. Public development program plans are usually made at the central (top) level and implemented by provincial and district agencies. People or society are often included without being given choices and opportunities to provide input. In this vision, the public is placed in a position that needs outside help.

In overcoming the Below Red Line incident, the government is carrying out programs such as growth monitoring, supplementary feeding and KADARZI programs that have not been maximized due to the lack of education by health workers and the role of the public actively. Toddlers Below the Red Line services should be provided in an integrated and comprehensive manner in order to prevent recurring malnutrition and infectious diseases in children. As a promotional service in the form of food education and children's health. Preventive services in the form of notification of underweight children, education of diet, weighing, referral to health workers and supplementary feeding. And improvement of curative services (Laurentia et al., 2016). Toddlers Below the Line services not only require the role of mothers and midwives, but the need for the support of doctors, specialist doctors for health education, then cadres and districts.

Indonesia is the 17th country from 117 countries that have complex nutrition problems, stunting, wasting and overwight. In order to overcome this nutritional problem in 2010 the United Nations launched the Scalling Up Nutrition (SUN) program, which was a joint effort by the government and the public to realize a vision of being free of food insecurity and malnutrition (zero hunger and malnutrition).

The program is also known as the First 1000 Days of Life (1000 DoL). Movement carried out by 61 countries in the world with the aim of eliminating various types of malnutrition. SUN is a global effort to strengthen commitments and action plans to accelerate nutrition improvement and also support the Sustainable Development Goals (SDGs) by protecting children's rights to obtain adequate nutrition (Rosha et al., 2016).

Like in India, there is the ICDS (Integrated Child Development Services Scheme) program, which was established 
in 1975 since they ranked 5th the highest country in the world with malnourished toddlers compared to Africa. Almost half of infants' deaths in India were caused by malnutrition (Dixit, Gupta and Dwivedi, 2018).

This program provides counseling to mothers regarding awareness of health risks, especially on children's nutritional status. In addition, it also emphasizes in the provision of nutritional supplementation, improvement of environmental hygiene and the practice of feeding children. In toddlers, Below the Red Line can be carried out in pharmacological and non-pharmacological handling efforts. Therefore, it is necessary to identify eating patterns or diet that include type of food, because toddlers who experience Below the Red Line, are usually caused by parents mistakes in giving nutritional intake (Safitri and Darmaning, 2016). The intervention had been running to prevent the occurrence of malnutrition, but the lack of public participation in the program also prevented the program from going well.

\section{CONCLUSION}

The mother's characteristic was age, occupation, education and mothers' knowledge can towards of behaviour their children's nutritional status and the incidence of toddlers Below the Red Lines. Maternal knowledge affecting the nutritional status of toddlers, especially in preventive measures for children $<5$ years old. In addition, mothers' participation to Posyandu can increase mothers' knowledge. Mothers will get information delivered by cadres and health workers through the counseling desk at Posyandu. The next factor is the level of education. Parents who graduated from higher education tend to choose balanced nutritional foods and give more attention to the nutrition intake.

\section{REFERENCE}

Boma, G. O. et al. (2014) 'Nutritional Status of Children in Rural setting . Nutritional Status of Children in Rural setting .', IOSR Journal of Dental and Medical Sciences, 13(1), pp. 41-47. doi: 10.9790/0853-13164147.

Dinas Kesehatan (2015) Profil Kesehatan
Kota Surabaya. Surabaya: Profil Kesehatan Kota Surabaya.

Dinas Kesehatan Kota Surabaya (2016a) 'Profil kesehatan Dinkes Kota Surabaya', p. 194. Available at: http://www.depkes.go.id/resources/ download/profil/PROFIL_KAB_KOTA_2 016/3578_Jatim_Kota_Surabaya_2016 .pdf.

Dinas Kesehatan Kota Surabaya (2016b) Rencana Strategis Tahun 2016-2021.

Dinas Kesehatan Kota Surabaya (2017) Profil Kesehatan Kota Surabaya.

Dixit, P., Gupta, A. and Dwivedi, L. K. (2018) 'Impact Evaluation of Integrated Child Development Services in Rural India: Propensity Score Matching Analysis', pp. 1-7. doi: 10.1177/2158244018785713.

Fitriani, N. (2018) 'Hubungan Kunjungan Ibu ke Posyandu dengan Jumlah Balita Bawah Garis Merah ( BGM ) di Desa Tente Kecamatan Woha Kabupaten Bima Correlation between Mother' s Activeness Integrated With Health Service Number Reduction of Toddler Below The Red Line ( BGM ) I', Jurnal Studi Keislaman dan Ilmu Pendidikan, 6(1), pp. 70-80.

Inayah, M. and Hartono, M. (2016) 'PENGARUH PEMBERIAN MAKANAN TAMBAHAN DAN STIMULASI TERHADAP PERTUMBUHAN DAN PERKEMBANGAN BALITA BGM USIA 1-2 TAHUN', 02(01), pp. 61-70.

Kementerian Kesehatan Republik Indonesia (2010) 'Penggunaan Kartu Menuju Sehat (KMS) Bagi Balita'.

Kementerian Kesehatan Republik Indonesia, $2018 \quad$ (2018) Profile Kesehatan Indonesia Tahun 2017, Ministry of Health Indonesia. doi: 10.1002/qj.

Larasati, M. D. (2019) 'STATUS GIZI BALITA BGM BERDASARKAN KARAKTERISTIK IBU DI WILAYAH KERJA KECAMATAN SAWAH BESAR TAHUN 2018', Jurnal JKTF, 4(1).

Laurentia, L. M. et al. (2016) 'Gambaran Pelayanan Terintegrasi dan Komprehensif pada Balita Bawah Garis Merah di Puskesmas Soreang Illustration of Integrated and Comprehensive Health Services for Under', 2, pp. 192-199.

Lisang, A. G. (2017) 'IMPLEMENTASI PROGRAM PENANGGULANGAN GIZI BURUK PADA ANAK BAWAH LIMA TAHUN PADA DINAS KESEHATAN', $e$ 
Jurnal Katalogis, 5(2), pp. 14-25.

Notoatmodjo, S. (2010) Promosi Kesehatan Teori dan Ilmu Perilaku, Jakarta: Rineka Cipta.

Novitasari, Destriatania, S. and Febry, F. (2016) 'Di Puskesmas Awal Terusan Determinants Occurrence of Toddlers Below the Red Line in Health Center of Awal Terusan', Jurnal IImu Kesehatan Masyarakat, 7(1), pp. 4863.

Nurul Budi Lestari1 (2016) 'Faktor-Faktor Yang Berhubungan Dengan Kejadian Balita BGM di Desa Karangpasar Wilayah Kerja Puskesmas Tegowanu', Universitas Muhammadiyah Semarang, 5(1), pp. 1-7. Available at: https://jurnal.unimus.ac.id/index.ph $\mathrm{p} /$ jgizi/article/view/1940.

Purnama Sari, D., Laenggeng, A. H. and Tasya, Z. (2016) 'HUBUNGAN TINGKAT PENGETAHUAN IBU DAN STATUS EKONOMI KELUARGA DENGAN KEJADIAN ANAK BALITA BAWAH GARIS MERAH (BGM) DI WILAYAH KERJA PUSKESMAS NOKILALAKI'.

Puspasari, N. and Andriani, M. (2017) 'Hubungan Pengetahuan Ibu tentang Gizi dan Asupan Makan Balita dengan Status Gizi Balita ( BB / U ) Usia 12-24 Bulan Association Mother' s Nutrition Knowledge and Toddler's Nutrition Intake with Toddler' s Nutritional Status ( WAZ) at the Age $12-24 \mathrm{M}$ ', Amerta Nutr, 3(2), pp. 369-378. doi: 10.20473/amnt.v1.i4.2017.369-378.
Rachmayanti, R. D. (2017) 'Pengenalan Program Kadarzi Di Kelurahan', (2018), pp. 176-182. doi: 10.20473/mgi.v13i2.176.

Rahma, A. C. and Nadhiroh, S. R. (2016) 'Perbedaan sosial ekonomi dan pengetahuan gizi ibu balita gizi kurang dan gizi normal', Media Gizi Indonesia, 11(1), pp. 55-60.

Rahmatillah, D. (2018) 'Hubungan Pengetahuan Sikap dan Tindakan terhadap Status Gizi', Amerta Nutr, pp. 106-112.

RISKESDAS (2018) 'Laporan Nasional Riset Kesehatan Dasar 2018'.

Rosha, B. et al. (2016) 'Peran Intervensi Gizi Spesifik dan Sensitif dalam Perbaikan Masalah Gizi Balita di Kota Bogor', 1(12), pp. 127-138.

Rozali, N. A., Subagyo, B. and Widhiyastuti, E. (2016) 'Abstrak Peranan Pendidikan, Pekerjaan Ibu Dan Pendapatan Keluarga Terhadap Status Gizi Balita Di Posyandu Rw 24 Dan 08 Wilayah Kerja Puskesmas Nusukan Kota Surakarta'. Available at:

http://eprints.ums.ac.id/41781/1/Na skah Publikasi Nur Azikin Rozali.pdf.

Safitri, Y. and Darmaning, I. (2016) 'POLA MAKAN BATITA "Z" DENGAN STATUS GIZI BGM (BAWAH GARIS MERAH) DI PUSKESMAS KETAWANG KABUPATEN MALANG', Jurnal Hesti Wira Sakti, 4(1), pp. 94-100. 